Илијана Р. Чутура

Универзитет у Крагујевцу

Факултет педагошких наука у Јагодини

https://doi.org/10.18485/ai_beckovic.2019.ch14

821.163.41.09-1 Бећковић М.

811.163.41'367.62

\title{
ЛЕКСЕМЕ СА ЗНАЧЕЊЕМ ВРЕМЕНА У ПОЕЗИЈИ МАТИЈЕ БЕЋКОВИЋА
}

У раду се утврђује фреквенција појављивања одређених семантичких типова лексема - прилошких и именичких - са значењем времена у збиркама Рече ми један чоек и Хлеба и језика Матије Бећковића. Анализирају се употреба и функције лексема са значењем времена и конструкција и синтагми у којима оне носе значење, њихово место у семантичкој структури текста, као и њихов стилски потенцијал. На тај начин рад пружа полазни материјал за књижевнонаучни приступ Бећковићевој прози са овог аспекта.

Показује се да Бећковић изразито често употребљава лексеме са значењем неодређене и универзалне темпоралне локализације или њихове спојеве, у суодносу са семантички сродним прилозима и именицама. Такође, биографско време лирског субјекта јавља се као једна од веома значајних компоненти. На стилском плану, доминирају антитетичке фигуре, понављања и кумулација као јасни сигнали важног места које категорија темпоралности има у анализираним збиркама.

Къучне речи: поезија Матије Бећковића, време, темпорална локализација, неодређена локализација, универзална локализација, биографско време.

* ilijana.cutura@gmail.com

** Рад је настао у оквиру пројекта 178014 Динамика структура савременог српског језика, који финансира Министарство просвете, науке и технолошког развоја Републике Србије. 


\section{1. Уводне напомене}

Предмет анализе у овом раду јесу лексеме, конструкције и синтагме са значењем времена у поезији Матије Бећковића. Истражују се њихови семантички типови, њихово место у семантичкој структури текста, и њихов стилски потенцијал. Корпус рада чине песничке збирке Рече ми један чоек и Хлеба и језика.

У анализираним збиркама, како се показује, на време упућују најчешће прилози и именице; ређе су то придеви (типа данашъи, садашғи). Што се глагола тиче, изван предмета истраживања остали су глаголски облици, али се (додуше ретко) региструју глаголске лексеме које својим лексичким значењем реферишу на време (као што је глагол омркнути).

Међу писцима „чији је стилистички поступак био везан за отклон од нормираног језика" (Милановић 2002: 50) Матија Бећковић има „изузетно место јер је први у српску књижевност увео дијалекатску поезију" (Исто: 51). Међутим, Милановић даље наводи да у поезији Матије Бећковића стилски потенцијал не носи дијалекат као чисто неоргански идиом већ његов суоднос са књижевним језиком јер, како истиче Ковачевић, „због минималних диференцијалних особина органског и неорганског идиома особине органског идиома намећу привид свјесног стилистичког структурисања неорганског идиома. Односно текст поема читалац по правилу перципира из перспективе стандарднојезичког израза, док наносе органског а некњижевног (специфично ровачког и шире источнохерцеговачког) у перцепцији схвата као стилематичне оазе које не негирају стандарднојезички карактер текста (језика). Тако је избор органског идиома са минималним разликама у односу на књижевни језик готово сам по себи предодредио да особине тог идиома дођу у други план и да се перципирају као стилистичко струк- 
турисање текста, тј. као стилеми" (Ковачевић 1995: 104). Као и остала лексика, и лексички слој који у раду анализирамо садржи дијалектизме и специфичне Бећковићеве лексеме које наликују дијалекатским (нпр. тисивијек, задовијек, у један маг). ${ }^{1}$

У анализираном корпусу уочавају се и правилности у употреби лексема и конструкција са временским значењем. Те правилности су изненађујуће по доследности, семантичкој прегнантности и стилском потенцијалу, а остварују се на различите начине на нивоу појединачних песама. У њима, наиме, или нема готово никакве темпоралне локализације (понекад нити иједне лексеме која би упутила на време), тако да су потпуно „обезвремењене”, или је време доминантна семантичка категорија која истакнуту позицију добија фреквентном употребом, често и понављањем, лексема или конструкција са темпоралним значењем. Иако временска клауза није предмет наше анализе, свакако треба истаћи да се и оне на веома сличан начин укључују у семантички и стилогени темпорални оквир Бећковићеве поезије. Често су на „јаким” позицијама - на почетку као уводна локализација која даје кључни контекст или на крају, као поента, на пример: „Док је бог постојао, / Боже ме опрости, / Није имао бољијег љуђи од Црногораца" (РМЈЧ: 134).

Истраживање семантичке и стилске улоге лексема са временским значењем посебно је значајно за Бећковићеву поезију с обзиром на то да је Бећковић, како Микић каже, „певач прича” који негује специфичну поетску форму у коју укључује поетску нарацију: „Разлога да Бећковић буде певач прича има више (и код њега

1 На пример: „Један је таки најпотлашюе - / џидом од барјака скроб мијешо, / А ти ако биднеш имо и скроба! / Једнога таквога су најпотље у помамилу ватали (РМЈЧ: 26)". Остали стихови у којима се наведене лексеме јављају наводе се и лоцирају у даљем тексту, у одговарајућим одељцима. 
је сасвим особена епска компонента наше традиције добила важну улогу, она је, сасвим сигурно, утицала на то да се овај песник определи за дуге књижевне облике, поеме, дуги облици траже причу, прича, пак, о једном специфичном поднебљу и људима тог поднебља тражи особен језик...)" (Микић 2002: 26). Поред тога, важно место које Бећковић даје лексемама са значењем времена и начин на који лексички и синтаксички „манипулише” њима можда су највидљивији из наслова књиге $O$ међувремену, где се лексема међувреме осамостаљује из потпуно блокираног прилошког израза у међувремену, у којем се искључиво јавља увек у истом облику и са истим предлогом. Бећковић декомпонује овај устаљени израз који попуњава празно место у систему временских значења, односно место за које нема адекватног прилога (Ковачевић 2007: 45-46).

\section{2. Типологија лексема са значењем времена у Бећковићевој поезији}

Сходно жанровској одредници Бећковићеве поезије, „прича” укључује и низање догађаја по одређеном наративном редоследу, а тиме и учешће лексема (пре свега прилога и именичких/прилошких лексема у оквиру прилошких одредби) са значењем темпоралне локализације. У овом систему лако се може запазити читав низ лексема са временским значењем, од којих неке припадају стандарду, неке лексици са архаичним призвуком, а неке дијалекатском слоју:

(a) деиктички заменички прилози - локализација идентификационог типа и њене аблативне/адлативне варијанте $^{2}$

2 О семантичким карактеристикама прилога и њиховој 
Taде су га одвели и спратили (РМЈЧ: 95); Таде ни нијесу манисали (РМЈЧ: 115); Ја ову жену досад нисам гледала (Хиј: 79); Људи су ме тако цијенили досад, / а тако мислим и посад (РМЈЧ: 9); Нијесу ш њима могле печеније очи, / Нико досад ни мимосад (РМЈЧ: 31); Осетих да отад он живи у мени (Хиј: 125)

(б) прилози и изрази са обележјем антериорности (који често укључују компоненту дисталности)

Ти си мени однекуд познат / Као да сам те негде и раније гледао (Хиј: 103); А послије било им сумњиво, / Зашто да баш у Ровца живимо, / Ђе прије нас нико никад није (РМЈЧ: 96); Нити се с Турцима знао одраније / Из шуровања и домунђавања (Хиј: 97)

Тек кад су му одсекли главу / Подигао се из траве // [...] // Да је носио на раменима / Давно би остао без ње (ХиЈ: 99-100); Да јој је требало, / Давно би узела, Кад је била куветнија! (РМЈЧ: 116); мислили су давно ћу муве окупит (РМЈЧ: 68); Но ево и у букварима, / Поодавно нема нове приче! (РМЈЧ: 93); Док су били у најљућој завади / Како је одавно уведено у обичај (Хиј: 97); Које више не говоре / Чавке-удовице / Већ одавно покојне (Хиј: 74)

(в) изрази са именичким лексемама општег временског значења (вр(иј)еме, доба, вакат)

Били су најбољи док иг је било! / Били су најбољи у најбоље вријеме! (РМЈЧ: 111); Не могу Црногорци постојати - / У свакоме времену! (РМЈЧ: 113); Шћедо да данем, да се позорим, више је вакат (РМЈЧ: 27); То је било у они вакат! / У ондашњу њину државу! (РМЈЧ: 77); Све у свој вакат, па и она! (РМЈЧ: 103); Превера се подразумевала / Јер се у оно доба још није знало / Да се туђој вери може боље служити

типологији в. Пипер 1988 ; збирке су у даљем тексту означене скраћеницама „ХиЈ” (Хлеба и језика) и „РМЈЧ” (Рече ми један чоек) 
/ Ако се остане у својој (Хиј: 74)

(г) лексеме и изрази са значењем године

Као и ове године (Хи): 123); А да је нама неко тако, / Не бисмо му остали дужни, / Да ће на врг девете године! (РМЈЧ: 80); А ова година знаш каква је била (РМЈЧ: 10); А u сад после толико година / Кад год се сусретнемо / Ја и та жена / Стид ме од ње (Хиј: 81-82); И када смо после толико година / Дочекали да чујемо / Те исте речи / Већ стасале у државне / А намењене истој сирочади / Већ под седином (Хиј: 74);

Као лағски лист у новој трави / Прометао се кроз себе (Хиј: 98)

Догодине ћеш у школу (Хиј: 63).

Како би се утврдила структура семантичког поља темпоралности у Бећковићевој поезији, значајно је утврдити и својеврсну типологију времена с обзиром на природу означених периода. Пре свега, приметно је да доминира „микровреме” - лето, сабор, јутро, вече... Историјски, друштвено-политички контекст, који изузетно често чини окосницу песме и доминира лирско-драмским сукобом, ретко се ишчитава из директне локализације („Уз рат или по рату” у песми Долазак; „У безглавији иза рата” у песми Без икога, „оних поратних година" у песми Краљ Петар II) већ се на њега упућује посредно, понекад чак и тако суптилним средствима као што је графостилемска интервенција (нпр. употребом великих слова у синтагми „Велики Народни Сабор” у песми Који је оно, мајко? где се великим словом у речи народни сугерише историјско време посредством доминантне политичке парадигме). ${ }^{3}$

3 У овој песми графостилеми управо упућују на темпорални оквир дефинисан друштвеним околностима: „Карневалска детронизација, својствена гротесци, таква је и толика да је главни говорник претворен у 'Црну Рупу насред Бијелог Поља', препуну сувих мува. Преображај је потпун тек када казивачева мајка у тој 'Црној 
Готово на нивоу изузетка јавља се прецизна локализација у овом смислу, као у наслову Путоване у Свету земъу уочи двехиљадитог Христовог рођендана (ХиЈ) или „Прави је Црногорац бјен 909, / Од своје власти” (РМЈЧ: 96, Шпијун у Ровцима).

Међутим, и поред ретког исказивања прецизног временског оквира у овом смислу, у анализираним збиркама могу се утврдити лексичко-семантичке доминанте у пољу темпоралности. По своме присуству у овим двема збиркама, као оријентири издвајају се биографско време лирског субјекта, природни периоди дана и доба године, а као семантички подтипови универзална и неодређена локализација.

\section{1. Биографско време лирског субјекта}

Биографско време лирског субјекта доминира песмама чија су поетска окосница очекивања од недорасле деце и њихове наметнуте обавезе зрелог понашања. Често истицана, драматична позиција лирског субјекта с обзиром на контраст између очекивања и младости условљена је околностима у којима се одраста у специфичном црногорском амбијенту („Е Црна Гора нема другијег жена - / Нако сестара! / Ни другијег пјесама - / Нако тужбалица! / Ни ђеце - / Нако посмрчади!” (РМЈЧ: 131); „Споро сазревамо / Рађамо се до смрти / У младости спремни на свашто / А како старимо / Бивамо бољи људи” (ХиЈ: 47); „Још мало да порастете / Па ће све бити / Као кад смо били живи" (ХиЈ: 73, Без икога)).

Оваква драма лирског субјекта најексплицитније је исказана, на граници са парадоксом, у песми Нuсu тu више мали:

Рупи’ препозна убицу казивачевог оца" (Делић 2002: 58). 
Ђед ти је млађи био / Кад је осто сироче / Али је био рођени чоек / Рођен као старац / Откад је пробечио / Себи је све забранио / У мањим годинама / Кућу је одржао / И мајку отхранио / Здрав ми ти био (Хиј: 68);

Давно си оседео / И постао ђед / Погледај се колик си / Кад мислиш да одрастеш (Хиј: 70).

Детиње виђење света кулминира у песми Који је оно, мајко?, чија је и идејна окосница. Исповешћу одраслог човека (сада „приповедача”) о сопственом доживљају драматичних тренутака свог детињства, Бећковић не ремети позицију лирског субјекта увођењем наративно надређене инстанце у виду друге особе, већ оставља „Приповедача” да самостално и искључиво обликује свој доживљај. То Бећковић чини из двоструке визуре: лирског субјекта као детета, где доживљај из те позиције не губи на интензитету, и из визуре лирског субјекта из другог времена (времена приповедања): ${ }^{4}$

Био сам већ младићак / [...] / Са више година него кила / Кад ме је јатка одвојила од јаради / Подшишкала и зачешљала / Обукла очеве гаће и кабаницу / и повела у Бијело Поље / На Велики Народни Сабор / Да уведе међу људе / И покаже ђевојкама / Свога јединка / И доскока крвницима (Хи): 51, Који је оно, мајко?)

Тако виђење догађаја остаје аутентично доживљавање света из наивне свести, света који „израста постепено у ужасавајућу и трагичну целину” (Илић 2010: 210).

Биографско време лирског субјекта лексички се експлицира и у оквирима универзалне темпоралне квантификације која се омеђава границама људског живота:

4 Упор. начин на који Драгослав Михаиловић конструише приповедање из позиције „наивне свести” (Јовановић, Чутура 2013: 49-56). 
Вишега чуда нијесам чуја у моје дневи (РМЈЧ: 8); И све што си чуо у свијету / Снаће те у вијеку (РМЈЧ: 23); Више сам ја изио траве / у моме јадовијеку, / но што је звијезда у небу (РМЈЧ: 67); Ово док сам жива (ХиЈ: 82, Стид); Речима се замајавам / На језик се дочекујем / Да се жив чујем / До ћутне минуте (Хи): 31 ).

\section{2. Природни циклични периоди - дан, делови дана, годишња доба}

Лексеме које означавају природне цикличне периоде један су од доминантних типова лексема са значењем времена у Бећковићевој поезији.

Опозиција између ноћи и дана, светлости и таме, изузетно је значајна и добија свој симболички трансфер на идејном плану (контрастирање светлости и таме као опозиција некадашњег херојства, чојства и јунаштва према супротним карактеристикама националног опадања). Занимљиво је да Лабуд Драгић у роману Кукавичја пилад посеже за истим контрастом како би исказали светлост и мрак Црне Горе. ${ }^{5}$ Међутим, док се у Драгићевом роману догађаји одвијају у тами или на светлости, код Бећковића је кључни период осенчени део дана, сфумато и магновење

5 У роману Кукавичја пилад, „[о]понирању светлог и тамног периода дана придружује се и често контрастирање на плану аудитивних сензација. Поред пресудне, подразумеване, улоге околности у којима се комуникација одвија, што условљава свестан избор интензитета говора од стране јунака, као да поред мрака и мук готово лајтмотивски прожима роман” (Чутура 2017: 97); „временски прилози и прилошки изрази са значењем мрачних периода дана заједно са начинским прилозима који означавају снижен интензитет говора или његово потпуно изостајање као пропратну околност вршења радње, учествују у креирању атмосфере романа која је мрачна, пуна скривања и неповерења. Међутим, рекли бисмо да тама и мук имају и своју симболичку функцију, уоквирујући атмосфером хаоса и песимизма моменат у којем је, како се наслућује, започео један дуготрајни процес" (Исто: 99). 
између ноћи и дана. Најзначајније драме догађају се у освит зоре, у сумрак, у међупериодима означеним именицама дан, ноћ, зора, поподне (и глаголским именицама, нпр. расвит, смировиште) или конструкцијама типа у навод суни, у и ик зоре, у петлове и, ређе, глаголским лексемама са значењем смене периода дана, типа разданити ce:

Дан је већ кретао да иде / А кокошка се још гнездила и скањивала (ХиЈ: 38); Уз рат или по рату / Таман негде у ова доба / Тек што се смирио дан / И преминуло сунце / Стајала је њих пешестина код цркве (ХиЈ: 10); Где ништа не цвета / Сем ако не цвета ноћу (Хиј: 46); А деси се да не бијелим ока на око, / По цијелу драговетну ноћ (РМЈЧ: 90); Па се опуштених руку и постиђених леђа / У навод сунца ломовраћала кући (ХиЈ: 58); Кад су је пустили из затвора / Она није знала куд да иде / Чекали су вече да је ослободе / А по ноћи није смела у планину / [...] / Плашила се да замоли кључара / Да је пусти назад док се не раздани (ХиЈ: 86); Дигли смо се у петлове (ХиЈ: 133); Једног од тих поподнева / На повратку с чајанке (ХиЈ: 101); Таман се дан од ноћи одвојио, / кад оно / [...] / таман у цик зоре, / а зове неко по имену та и та (РМЈЧ: 7); А Бог ти један, зађосмо у дебели дан (РМЈЧ: 8); Грану зора а он запарадио (РМЈЧ: 11); Тако ни прође дан и ној, двије полуредице, / све од расвита до смировишта, / грану ли то зора - ограну богоми, / не умјесмо се раздвојит (РМЈЧ: 11-12); Остани ту неђе до у заранке (РМЈЧ: 57); С обућом у руци ишла сам пред њиме / Чекајући пуцањ у леђа / И у оном мркломе мраку / Срећна што се деца нису пробудила / Надала се да нећу чекати дуго (ХиЈ: 89-90, Jеја); Сву ноћ смо тутали уз оне кукове / [...] А испред зоре / Избили на издушак клисуре // [...] // Горе као да није стигао / Чоек на једну воду / који је синоћ кренуо из долине // [...] // Као да му се у души разданило / И као вампир који у расвиће одустаје (ХиЈ: 90, Јеја) 
Значајна је фреквентност и прилошких лексема овога поља: jympoc, данас, c(j)ympa, јуче). Прилог данас се, при том, јавља и у значењу дужег периода „у данашње време":

А такијег је данас понајвише! (РМЈЧ: 128); Причам ти ко да ћу сјутра да мрем, / ово без тебе данас нијесам никоме (РМЈЧ: 8); а кад биг знао, / да би ми и трећи дио од онога било, / и да би ме ико лелекнуо, / cjympa биг се убио (РМЈЧ: 60); Но кад би се сјутра заратило / Ми би чули кад се рат заврши! (РМЈЧ: 97); Сјете се данас што су требали јуче (РМЈЧ: 87); Не чула ми се до Цуња Шпијова, / Е сам јутрос гласно срце опро, А у гору гласно се не збори (РМЈЧ: 99).

Називи дана у седмици или назнаке годишњих доба и празника, у складу са темпоралном неодређеношћу као једном од доминанти Бећковићеве поезије, појављују се знатно ређе од претходних типова лексема. У корпусу смо их регистровали као елементе конструкција које углавном и не остварују прецизну временску локализацију (у другом наведеном примеру са значењем регуларног понављања):

То је било неђе овако: / субота и субота петнаес / и неђеља шеснаес / и седамнаести дан Мала Госпођа! (РМЈЧ: 53, Смрт Перка Пушелина); Па у оне крше дежурају, / И неђељом кад нико не ради (РМЈЧ: 97, Шпијун у Ровцима); По тетьој смлатимозговиии (Хи): 53); Ајде јадна / Удари се по устима / На Божић / Код онога извора / Дала си ми зеру чеснице (Хиј: 79-80).

\section{3. Универзална темпорална локализација}

У анализираним збиркама можда је најзначајнија временска категорија универзална темпорална локализација која се најчешће остварује прилозима никад, увијек (и у 
екавској варијанти увек), ${ }^{6}$ вазда или семантички аналогним изразима.

У овој групи, прилог вазда је један од најфреквентнијих временских прилога у анализираном корпусу, што потврђујемо следећим примерима:

Не жали да се замериш фукари / Вазда јој треба пропуштати кроз нос / Ко је и шта је (ХиЈ: 115); Људи су им јадан шиљак у нос вазда били (РМЈЧ: 29); вазда су њиг двојица имали нешто насамо и натајно (РМЈЧ: 57); а Перко је вазда имао оне јаниџе (РМЈЧ: 57); од кад сам настао, / вазда сам у неку потоњу границу (РМЈЧ: 64); Вазда смо зборили из пунијег уста (РМЈЧ: 70); Ђе смо гој били људски смо глас донијели, / [...] / Вазда укабулили, горњали се, друге соколили, / Вазда призивани и пропиткивани (РМЈЧ: 74); А ко си ти? / Вазда пунијег крила и тврдијег очију, / Вазда гледали истини у зенице (РМЈЧ: 75); Ти вазда о своме, чини се невјешт (РМЈЧ: 77); А вазда смо гинули да не би умирали (РМЈЧ: 78); Од прве ништа не разумију, / Но вазда поново питају (РМЈЧ: 85); Вазда шераиле, вавијек насмејани, / Цио вијек им прође у гајрету! / Све им је згодно за пјесму и светковину, / Вазда им је пазарни дан (РМЈЧ: 87); Немају кад једино радити, / Но им се вазда нешто испријечи! (РМЈЧ: 88); Вазда веле: наљегли случајно! (РМЈЧ: 97); Па не знамо ни што то не чине / Ни зашто смо вазда под присмотром! (РМЈЧ: 97); А жртве су вазда ближе циљу, / Но циљ оним који побиједе! (РМЈЧ: 121); Ни одвајати, ни ограђивати, / Е је вазда била одвојена (РМЈЧ: 124); Нако ћемо одшегат од копна, / Па ћерати у море, Оно што је вазда било наше! (РМЈЧ: 124).

6 То се мене увијек шћело, / да ме снађу јади на правди Вишњега (РМЈЧ: 10); Све хоћу да ти кажем / А увек заборавим (Хиј: 32); Као увек око Савина дана (Хиј: 123); И крушка и пут и моја кућа / Нестали су под гомилом камења / Над којом је искрсло питање / Налик на крушку грдосију / Јесмо ли ломили небо / И каменовали звезде / Или отресали крушке / Из небеских недара / Док не остане само једна / Која се више пела / Што је више обарана / Да увијек сија / А никад не опадне (Хиј: 47-48) 
Поред њега, појављује се - ређе - и низ лексема са истим или сличним значењем, од којих су неке дијалекатске, као и конструкција дан данас (понекад писана спојено, а понекад одвојено), на пример:

Кукај и жали се тисивијек (РМЈЧ: 77); Леле мене браћо Црногорци, / И за Црном Гором с вашега краја, / Данас па задовијек! (РМЈЧ: 133); Ако знам знало ме ћорило, / У оба ова ћоратка, / Што и задовијек, ето зашто! (РМЈЧ: 94); Но само да видиш шта су жестоке иксанске муке, / Дако би ти пукло пред очи, / Једном па занавијек (РМЈЧ: 24);

Ето кад се то збило и казало / Ко би / Шта би / Дан данас се није дознало (Хиј: 11); Путник је најпре саставио три прста / Како је одредио да се и ми крстимо / Плашећи их знаком / Од кога су још више побеснели / А ни до дан данас нису узмакнули (Хиј: 123); А ни данданас не знам зашто (РМЈЧ: 68).

Негативна универзална локализација остварује се најчешће прилошком лексемом никад(a). Изузетно висока фреквенција овог прилога има упориште у „поетици негативних пророчанстава”: „Ко чита или макар слуша стихове Матије Бећковића видеће да у њима, хуморним преображајем реторично-патетичких пророчких праузора, стално изнова формулише свет негативних пророчанстава" (Пантић 2002: 77). С друге стране, у Бећковићевој поезији честа је и опозиција између традиционалног система вредности и његовог ништења у садашњости, што се исказује квалификацијом онога што се догађа у савремено доба а што никад није било:

Те живни, живни, нећемо никад / виђи ђе је сунце, заранци, омркосмо, те та дан ту оста (РМЈЧ: 8); неће имати никад ништа, / ни кљетаре, ни мегаре, ни кере, ни кемпе, / ниђе

7 Ова три стиха рефренски се понављају у песми Долазак на крају првих пет од укупно шест строфа. 
ништа сем уво под главу (РМЈЧ: 70); И чекамо / Да нешто дочекамо / Или нађемо нешто / Па никад ништа (Хиј: 18); Никад се никоме нијесмо склањали (РМЈЧ: 73); А неће (никад вище), / Само оно што не могу, / Чеса више и нема! (РМЈЧ: 88); Оће ли икад бити - / Оно што никад није било!? (РМЈЧ: 89); А никад никакву тајну знали нијесмо (РМЈЧ: 93); Ко, клети, имају и од чега и на чему, / Па им никад није доста (РМЈЧ: 105); То што оће - никад није било (РМЈЧ: 121); Оплакује изгубљену славу, / Која никад постојала није / Нако кроз њен плач и погибију! (РМЈЧ: 121); И било је како није било, / Како никад и не може бити (РМЈЧ: 121); У њој никад није ни било народа! (РМЈЧ: 127); Од кад знам за себе, / на јад ми је сваки дан дошо, / све тегли од звијезде до звијезде, / и никад различитога дана, / и никад људскога оброка (РМЈЧ: 65); Кад изби чоек с оне стране / Код онога извора / Што никад не пресушује (Хи): 10); Кад се мислиш уљудити / И људима одужити / Ко не почне одмах / Неће никад (Хи): 68); Зарекао си се / Да мајку сахраниш / А да је никад ничим не обрадујеш (ХиЈ: 72); У мојој се кући задомаћио / [...] / И столицом оном застоличио / У којој туђинац никад није седео (Хиј: 111); Да се никад не сазна / Ко је кога убио (Хиј: 125); Рече ми тај човек, / којега никад очима нијесам видио (РМЈЧ: 9); Највише Ништа на Земљи, / Никад им нико није бранио да бидну љуђи (РМЈЧ: 30); знам, иљаду година да живим, / никад ништа ниоткуд чути нећу, / нако црнијег гласова и абера (РМЈЧ: 64); И никада ништа не нађоше / Нит се може што у Ровца наћи (РМЈЧ: 98); Никад није било више гусала, / А никад се није мање гуслало! (РМЈЧ: 130).

И прилози и изрази који означавају тренутак говора своју стилогеност и семантизованост исказују у оквирима изузетно честе опозиције некад / сад: „А кад је реч о односу прошлости и садашњости у песмама/песничким причама Матије Бећковића, може се рећи да је тај однос добио неколико важних компонената. Она која је најважнија и која подређује себи све друге је садржана у идеализацији прошлости, свега што је било и што се више неће вратити. [...] То је разлог што плачући 'над Црном Гором', 
Бећковићев јунак и приповедач непрекидно говори о томе како је нечега некад било, а данас тога нема" (Микић 2002: 27-28). Бећковић „слави минули свет”; „данашњи свет је у његовој поезији само бледа сенка давне, херојске прошлости" (Пантић 2002: 76), те се, уз прилоге никад, некад и њима семантички сродне изразе, у контрастним сликама често јављају и лексеме и изрази са значењем садашњости:

Нема више онаквих / А боље што их нема / Не би сад ништа учинили / Овако мислимо да би они / А било би / Ево их / Па ни они. // Сад има да нас нема / И нека нас нема / Доста нас је и било (Хиј: 23); Шта сад да се чини, / Кумим ти стопе кудијен идеш, / Кад ни планине више нијесу, / Као што су некад биле, / Но се нешто смањиле и покуњиле!? (РМЈЧ: 104); Планине су расле с нашом погибијом, / Сад се не гине па се урастају! (РМЈЧ: 107); Имало иг је кад се гинуло, / Сад се не гине па иг нема! (РМЈЧ: 111); Сад смо остали и без посла и без вјере, / А наша је вјера виша од истине! (РМЈЧ: 132); Нека... нека тога сад! (РМЈЧ: 74, Двије пјесме) ${ }^{8}$

Нијесмо некад ш њима у једну воденицу, / Па ево шта ишчекасмо сва сило од неба, / Сад неће они с нама, / Ко је самро о једноме мливу, / Жене су им косе откивале, а данас поглај, / Дође вријеме, донесе им га, / Што није никад никоме његовоме (РМЈЧ: 30); Данас није нико нидочега дошо, / Да није понеђе понешто о понекоме реко! / Ела, ја ти велим, / Сад то нико не гледа (РМЈЧ: 76); Најприје бијаше јунака, / А сад онијег те о њима причају (РМЈЧ: 130); Није ово вријеме за Црногорце, / Шта би они данас чињели? (РМЈЧ: 130);

Ово никад није било. // И хтели смо оно / Што никад није било. // Ово нико не памти. // Сада је све што нико не памти. // [...] // Никад није било боље. // Али до зоре може бити / Да никад није било горе (Хиј: 146)

8 Курзив је изворни, а овим сегментом се песма и завршава.

9 Двема косим цртама означавамо крај једне и почетак наредне строфе 
У оквиру оваквих опозиција јављају се и именице време и доба као ознаке квалитативно друкчијих периода, а најчешће у оквиру израза са атрибутима којима се истиче различитост у односу на друге временске периоде (своје, такво, друго):

Потурчење је унапређење / Издаја најприроднија / Па се тако није ни звала / Већ храбри реализам / Пристајағе на своје време / Као што вода пристаје на сваки суд (Хиј: 98); И што знаш - не знај, / Такво је вријеме, / Не гледај шта је поштено, / Поштење је пропало / [...] / Ко ти ваља то ти је и отац и мајка! / Није вријеме за морал но за мораш! (РМЈ: 80); Друго вријеме тражи друге вјештине, / А други су бољи у тијем својијем вјештинама, / А ђе су други бољи - / Ту није мјесто Црногорцима! / А да се и у тијем данаштьим извјештимо, / Па да биднемо таман ко и најбољи (РМЈЧ: 111);

Онда је повео у Кучју улицу / На чијем је крају његова кућара / Па се Симо Кучка и Кучкина жена / У кучје доба у кучјој држави / Као кучићи склупчаше на земљу (Хиј: 88, Јунак и Кучка)

\section{4. Неодређена темпорална локализација}

Неодређена темпорална локализација једна је од најдоминантнијих временских одредница Бећковићеве поезије, а остварује се најчешће лексемама једном, кад, некад, икад (знатно ређе прилошким изразима типа у неко доба, y један маг). Ово показујемо следећим примерима:

И сад сам му то дужан / И хоћу ако једном / И моје очи дочекају да га виде / Ако би ми кад кућу напунио / Као да имам некога / [...] / Али ако би ме икад / и игде освинуо (Хиј: 13); не вјерујем да је икад иједан прошо, / да ми није нешто објесио на нос (РМЈЧ: 69); Ако бисмо кад шта градили / Као што нећемо (Хиј: 17); Коре не да ништа не радимо / Ко да смо кад што радили?! (РМЈЧ: 115) Ја бих знала да сам те некад срела (ХиЈ: 81) 
У неко доба прође Радивоје (ХиЈ: 87); Лаје шапов неће да утоли, / кад у један маг неко зазва / с одушње стране куће (РМJЧ: 53)

Говорећи о вербалним формулама као елементу Бећковићеве песничке реторике, Вуковић каже: „Већ у првој поеми прве књиге [Рече ми један чоек] Бећковић начиње једну такву формулу, развијајући невиђену умјетност околишења. Цијела поема је, у ствари, плес над празнином, одгађање одговора кога неће бити, невјероватна драматизација самог чина тајне” (Вуковић 1995: 36). Управо овај поступак драматизације тајне и говорења да се ништа не би казало има своје упориште у неодређености која се остварује и темпоралном неодређеношћу, где налазимо и кључ изузетно високе фреквенције лексема са значењем неодређене временске локализације у оквиру („бећковићевски” модификованих) формулативних исказа: „Неодређеност је, иначе, својство вербалних формула. Сјетимо се још једном почетка бајке: 'Био једном један цар... Који? Гдје и када? Не даје се такав одговор, као и на евентуална питања Бећковићу: 'Шта рече?' и 'Који човјек?' Ради се о интуитивној или свјесној индетерминацији којом се постиже слобода времена и простора. 'Зборио је некакав да је неђе неко, / Некоме нашем племенику, неђе настрану / Тамо њему некакав јабанац, / Рекао некакву бетну ријеч' - говори се у једној Бећковићевој поеми (Двије пјесме)” (Вуковић 1995: 37). Индетерминација као један од упоришних елемената Бећковићеве поетике остварује се и посебном врстом игре речима у којој се комбинују елементи неодређености у различитим категоријама, као у следећим стиховима:

Рече ми један чоек, / на једноме мјесту, / код једнога чоека, / једну ствар, / не могу ти рећи ђе, / одма би се сјетио који је (РМЈЧ: 7, Рече ми један чоек). 
Будући да је свакако реч о стилогеном поступку, те да је поступак комбиновања и умножавања истих семантичких елемената готово песнички манир у анализираним збиркама, о њему ће више речи бити у завршном одељку рада.

\section{3. Темпорална квантификација}

У корпусу су регистроване и лексеме и изрази са значењем темпоралне квантификације. Иако њихова улога у обликовању стилског и симболичког слоја песама није изражена у истој мери у којој би се то могло тврдити у вези са лексемама и изразима у пољу темпоралне локализације, издвајамо следеће типове: (а) значење дужег трајања, (б) значење кратког трајања, где доминирају (самостално или у оквиру израза) лексеме час, часком, трен, (в) физички периоди типа минут, сат, дан и (г) значење неодређености, где региструјемо израз једно време:

(а) Дуго је та књига / Чувана под девет брава (Хиј: 8); А нећу ни ја дуго / Па причај кад одем (ХиЈ: 28); Ко зна колико нисам знао за себе / Док сам почео да повезујем мисли (Хиј: 56);

(6) Некако ме подиже и накембери / Али ме замах застава оте из њених руку / И поче са мном млатити као с трањом / Час ме подижући међу звезде / Час враћајући назад у балеге (Хиј: 56); Напиши то часком / Што се врпољиш и гњездиш (Хиј: 40); Није је видео нико / А један је гледао / Не питај ко ни како / Чоек му је дао / Само на трен (Хиј: 8);

(в) Могао би да будеш најбољи / Да служиш за пример / Ништа лакше / Само да ме послушаш / И узмеш књигу / И овако је / Пола сата држиш у руци // Пола сата / Нu минут вище (Хиј: 71); Пола сата им је чупо носеве и 
бркове (РМЈЧ: 79); По годину сам себе наговарао / Да некога саслушам (Хиј: 28); Друга му тамо додило није, / ваздраги дан колико је ту било душе (РМЈЧ: 56); Ваздан чуче напразно и стењу (РМЈЧ: 96);

(г) Једно време су летели заједно / Крушка и камен / Да их је било тешко разликовати (ХиЈ: 44).

\section{4. Стилска маркираност}

Употреба временских адвербатива у поезији Матије Бећковића одликује се стилском маркираношћу која је у сагласју са фреквенцијом семантичких типова темпоралног одређења. Стилогеност лексема са темпоралним значењем везана је за појединачне песме, у којима се понављају исте временске одреднице или се кумулирају адвербативи исте диференцијалне семантике, Чак и када временско одређење изостаје, оно има своју стилску и симболичку улогу као „минус присутни знак” и маркер универзалности.

У песми Ниси ти више мали, на пример, појављује се низ прилога (временских, месних, начинских), пре свега заменичких. У следећим стиховима су просторни прилози, уз глаголе у императиву, готово једини носиоци значења:

Крени овуда / Немој туда / Шта ћеш онуда / Дођи овамо / Иди тамо / Не скићи тамо амо / Кућо темељита

Из строфе у строфу Бећковић гради таква понављања структура, у које спадају и временске клаузе:

Кад би певао / Сети се где ти је отац / Кад ти се игра / Помисли на браћу / Кад ти је све потаман / Упитај за сестре / Кад ти се шали / Знај да ти и најмању шалу / Бог у грехе уписује 
Слично је са песмом Судбина Крста Машанова, у којој игра репетицијом преузима примат над смисаоним и симболичким нивоом:

Има ли / иђе, иђе, иђе, / ишта, ишта, ишта / ново / да ми причаш? // Има ли / иокле, / иокле, / иокле, / икаквога јава и аваза? // Мога ли / икад, икад, икад, / ишто, ишто, ишто, / икако, икако, / иодкога / дознат, / да се црно чељаде, / ичему, ичему, ичему, / ичему, / тобожнада?

Свакоме, чини ми се, / барем некад, нешто, / пане с анђелом, / а мене никад, ништа, / мимо икога (РМЈЧ: 64, Судбина Крста Машанова)

Употребом лексема са временским значењем, Бећковић гради и оксиморонске ситуације, често дефинишући иреалне услове као препреку за остварење било каквог бољитка:

Требало би / Да није доикан / Отићи неђе / Да се има ђе / И гласно рећи / Но се нема шта / И прегнути нешто / Да се има рашта / А и да има / Било би залуду / Као што је и досад (Хиј: 18);

Да смо као што нисмо / Озидали бисмо је давно (Хиј: 19).

Овакав поступак кулминира у самој завршници збирке Рече ми један чоек, добијајући статус песничке поенте Бећковићеве поезије:

А што никад није било, / Увијек је било! / Онда ћути! / Нема не, / Постали смо други људи! (РМЈЧ: 135).

Како Ковачевић утврђује, оксиморон је иначе једно од обележја поезије Матије Бећковића: „Оксиморон као унутарреченични фигуративни стилем у Бећковића тежи да се изједначи са стихом, да постане реченица, јер реченица је права форма Бећковићева израза. [...] А на 
који начин Бећковић преводи логичку контрадикторност у смисаону хармонију, на који начин се површински 'бесмисао' претаче у дубински (поетски) смисао - најочигледније показују антитетичке фигуре изражене двостихом. [...] Пјеснички поступци извођења повишеног смисла из логички самоочигледног бесмисла исти су, наиме, и у синтагматском, и у стиховном, и у двостиховном фигуративном изразу" (Ковачевић 1995: 110-111). Додатно, анализом смо дошли до закључка да у збиркама које чине корпус овог рада лексеме са временским значењем имају кључну улогу у „претакању бесмисла у дубински смисао”. Један од примера које Ковачевић наводи, а који илуструје често посезање за временом као категоријом на којој се заснивају антитетичке фигуре јесте „Будућност је остатак прошлости / И биће је докле прошлост траје” (Леле и куку). Слични су поступци и у анализираним збиркама: релативизују се и линеарни ток времена (први пример) и биографско време (други), а појам трајања постаје субјективизован (трећа група примера):

Као да смо путовали унатрашке / И стигли пре него што смо кренули / [...] / Је ли се један дан понављао / Две хиљаде година / [...] / Сви су остајали при своме / а време свима давало за право (Хи); Путовате у Свету земљу уочи двехиладитог Христовог рођендана)

Кад је Свети Сава ишао по земљи / Још пре свога рођења / Док се звао Растко / Као што иде и сада / Само га не видимо / А можда је то било и доцније (ХиЈ: 122, Прича о Светом Сави); После свијег, кад се све заврши, / Кад сви изију своје будућности / Црногорска тад ће на ред доћи! (РМЈЧ: 121) Нема Црногорца што не би убио, / Ни такога да смрт не заслужи! / Мало живе, а дуго се памте, / Е смо дуже мртви него живи! / [...] Осим љуђи у њој ништа нема, / А љуђи су краткога вијека, / Од ње ништа останути неће, / Осим пјесме и осим камења! (РМЈЧ: 125); Лако је другијема, / Колико им је само вријеме! / Цио празни дан од расвита до 
смировишта, / Па јопет свани она божја јама, / Од двадес и четири сата! (РМЈЧ: 85, Лако је другијема); Ето у томе им брусни дан пролази (РМЈЧ: 86, Лако је другијема); Кад се назад у сенку повратила / Дрхтећи јер је била на слободи / На којој је време споро пролазило

Релативизација времена у Бећковићевој поезији, удружена са темпоралном неодређеношћу као једном од кључних доминанти, ствара симболичку слику времена. Време као физичка категорија готово да се повлачи пред њом и губи карактер мерљивости, слично као у митологији: „Овај свет, [...] свет боли и незнања, јесте свет који живи у знаку Времена. Ослобођење од овог света и задобијање спасења исто је што и ослобођење од космичког Времена" (Елијаде 1999: 84).

\section{5. Закључак}

Анализа фреквенције и семантичких типова лексема са значењем времена у двема песничким збиркама Матије Бећковића показала је да је поезија Матије Бећковића изузетно доследно обележена временском локализацијом - или изостанком било какве референције на време или наглашавањем таквог упућивања. Оба поступка су стилогена. Уколико се у песми појављује индикатор временског одређења, он ће се више пута поновити, а уколико песма није обележена временом, оно готово у потпуности изостаје.

Типови који се издвајају по фреквентности и стилогености, али и по учешћу у поетском обликовању саме суштине појединих песама јесу биографско време лирског субјекта, универзална и неодређена временска локализација, опозиција мрака и светлости изражена у периодима дана. Ови типови су уједно и преовлађујуће карактеристике песничких збирки које смо анализирали. 
Сасвим ретко се уочава прецизна темпорална локализација, а време као категорија бива релативизовано на два начина: антитетичким фигурама и давањем примата субјективном доживљају времена. Овакви поступци показују паралеле са митом који „трајно реактуелизује Велико Време и на тај начин преноси слушаоце у надљудску и надисторијску раван, што им између осталог омогућује да се приближе Стварности коју не могу досегнути у равни световне, индивидуалне егзистенције” (Елијаде 1999: 67). Другим речима, лексеме са временским значењем изузетно често учествују у обликовању свевремених поетских истина првог реда или у сликама заоштрених опозиција „некада - сада”.

На стилском плану, уочава се да се појединачне песме одликују или изостанком темпоралне компоненте или њеним истицањем (најчешће поступцима понављања или кумулације семантички сродних типова прилога и прилошких одредби).

\section{ИЗВОРИ}

РМЈЧ: Матија Бећковић, Рече ми један чоек, друго издање, Београд: Просвета, 1970.

Хиј: Матија Бећковић, Хлеба и језика, Београд: БИГЗ, 1997.

О међувремену: Матија Бећковић, О међувремену, записи, Београд: БИГЗ, 1985.

\section{ЛИТЕРАТУРА}

Вуковић 1995: Н. Вуковић, Вербалне формуле у функцији Бећковићеве пјесничке реторике, у: М. Вукићевић, Н. Вуковић, М. Ковачевић (прир.), Поетика Матије Бећковића, зборник, Подгорица - Никшић: Октоих - Филозофски факултет, 31-43. 
Делић 2002: J. Делић, Бећковићева гротеска (скица), у: С. Ж. Марковић (прир.), Поезија Матије Бећковића, зборник, „Десанкини мајски разговори”, књ. 9, Београд: Задужбина Десанке Максимовић, 53-63.

Елијаде 1999: М. Елијаде, Слике и симболи, огледи о магијско-ретигијској симболици (прев. Д. Јанић), Сремски Карловци Нови Сад: Издавачка књижарница Зорана Стојановића.

Илић 2010: Б. Илић, Поетички преображаји у приповедању Драгослава Михаиловића. У: Савремена проучавана језика и кюижевности, књ. 2, Крагујевац: Филолошко-уметнички факултет, 195-210.

Јовановић, Чутура 2013: В. Јовановић, И. Чутура, Книжевност за деиу и младе, поетика и тумачена, Јагодина: Факултет педагошких наука, 49-56.

Ковачевић 1995: М. Ковачевић, Антитетичка фигурација у поезији Матије Бећковића, у: М. Вукићевић, Н. Вуковић, М. Ковачевић (прир.), Поетика Матије Бећковића, зборник, Подгорица Никшић: Октоих - Филозофски факултет, 103-118.

Ковачевић 2007: М. Ковачевић, Синтакса и семантика прилошких израза, у: М. Ковачевић, Србистичке теме, Крагујевац: Филолошко-уметнички факултет, 11-48.

Микић 2002: Р. Микић, Матија Бећковић као певач прича, у: Д. Хамовић (ур.), Матија Бећковић, песник, зборник. Краљево: Народна библиотека „Стефан Првовенчани”, 25-44.

Милановић 2002: А. Милановић, Бећковићева дијалекатска поезија и стилистичка норма, у: Д. Хамовић (ур.), Матија Бећковић, песник, зборник. Краљево: Народна библиотека „Стефан Првовенчни”, 45-55.

Пантић 2002: М. Пантић, Пророчки стилски синдром у поезији Матије Бећковића, у: Д. Хамовић (ур.), Матија Бећковић, песник, зборник. Краљево: Народна библиотека „Стефан Првовенчани", 73-80.

Пипер 1988: П. Пипер, Заменички прилози у српскохрватском, руском и польком језику (семантичка студија), Београд: Институт за српскохрватски језик, Библиотека Јужнословенског филолога.

Чутура 2017: И. Чутура, Значење и стилистика прилога у роману Кукавичја пилад Лабуда Драгића, Узданища 14/2, 83-100. 
Ilijana R. Čutura

\section{WORDS WITH TEMPORAL MEANING IN MATIJA BEĆKOVIĆ'S POETRY}

The paper analyses frequency and stylistic features of the words with temporal meaning (mostly adverbs and nouns) in Matija Bećkovićs poetry (i.e. in collections Reče mi jedan čoek and Hleba $i$ jezika). The most frequent words belong to the following semantic types: biographic time (often connected to childhood or youth), universal temporal localization, indeterminate localization and adverbs and nouns which contrast darkness to light. Precise temporal localization is very rare and, additionally, the time as category is relativized in two ways: by anthitetical figures and subjective treatment.

Stylistically, the poems are characterized either by absence of temporality or its' prominence, which is achieved through repetition and cumulation of semantically similar types of adverbials.

Key words: Matija Bećkovićss poetry, time, temporal localization, indeterminate localization, universal localization, biographic time. 